Website. http://hilirisasi.lppm.unand.ac.id

e-ISSN: 2621-7198

\title{
MIKOALGA SPIRULINA PLATENSIS SEBAGAI SUPLEMEN UNTUK MENINGKATKAN GIZI DAN IMUNITAS BALITA DI POSYANDU ANGGREK 2 KELURAHAN SEBERANG PADANG, KOTA PADANG
}

\author{
Armaini $^{\left.1^{*}\right)}$, Yetria Rilda ${ }^{1}$, dan Netti Suharti ${ }^{2}$ \\ 1) Kimia-FMIPA Universitas Andalas \\ 2) Fakultas Farmasi Universitas Andalas \\ *)Email: armaini@sci.unand.ac.id
}

\begin{abstract}
ABSTRAK
Penderita gizi kurang dan gizi buruk terbanyak pada balita usia emas di bawah 2 tahun. Berdasarkan survei yg dilakukan ditemukan balita anggota Posyandu Anggrek 2 mengalami gizi kurang dan gizi buruk. Program kemitraan masyarakat memberikan solusi untuk peningkatan gizi terutama balita dengan memanfaatkan mikroalga Spirullina platensis yang kaya nutrisi sebagai suplemen gizi dalam menu makanan balita. Tujuan utama dari program kemitraan masyarakat yang dilaksanakan pada Posyandu Anggrek 2 adalah memberikan suplemen kapsul Spirullina platensis untuk memperbaiki gizi pada balita kurang gizi dan gizi buruk, meningkatkan pengetahuan pada ibu dari balita tentang makanan bergizi tinggi khususnya mikroalga Spirullina platensis untuk peningkatan gizi, imunitas dan kesehatan balita di masa pandemi Covid-19 saat ini. Penerapan teknologi budidaya Spirullina platensis yang di transfer kepada ibu rumah tangga yang tergabung dalam Posyandu Anggrek 2. Keberhasilan program ini terlihat bahwa pemberian kapsul Spirullina platensis pada 10 anak balita dalam waktu 6 minggu dapat meningkatkan gizi balita yang diukur berdasarkan indek Antropometri standar WHO. Peningkatan berat badan dan tinggi badan setelah pemberian Spirullina platensis terlihat pada semua balita, dan terjadi peningkatan kesehatan dan imunitas pada balita. Pemberian kapsul Spirullina platensis dapat memperbaiki status gizi dan imunitas pada balita.
\end{abstract}

Kata Kunci: Spirulina platensis, gizi buruk, balita, peningkatan gizi, imunitas

\section{Microalga Spirulina Platensis as the Supplement for Improving Nutrition and Immunity of Toddlers in Posyandu Anggrek 2 Kelurahan Seberang Padang, Padang City}

\begin{abstract}
Patients with malnutrition mostly were golden-age toddlers under two years. Based on the survey conducted, it was found toddlers of the Posyandu Anggrek 2 experienced malnutrition. The community partnership program provides solutions to improve nutrition, especially for toddlers, by utilizing the nutrient-rich Spirulina platensis microalgae as a nutritional supplement in the toddler's diet. The main objective of the community partnership program implemented at Posyandu Anggrek 2 is to provide Spirullina platensis capsule supplements to improve nutrition in under-fives with malnutrition and malnutrition, to increase knowledge of mothers of toddlers about highly nutritious foods, especially Spirullina platensis microalgae to improve nutrition, immunity and health toddlers during the current Covid-19 epidemic. The application of Spirulina platensis cultivation technology is transferred to homemakers who are members of Posyandu Anggrek 2. The success of this program shows that giving Spirulina platensis capsules to 10 toddlers for six weeks can increase toddler nutrition as measured based on the WHO standard Anthropometric index. The increase in body weight and height after administration of Spirulina platensis was seen in all toddlers, and there was an increase in health and immunity in toddlers. It can be concluded that giving Spirulina platensis capsules is beneficial for improving nutritional status and immunity in toddlers.
\end{abstract}

Keywords: Spirulina platensis, malnutrition, toddlers, increased nutrition, immunity 


\section{PENDAHULUAN}

Posyandu Anggrek 2 berada di Kelurahan Seberang Padang, Kecamatan Padang Selatan kota Padang. Pada saat ini masih ditemukan balita dengan kasus gizi kurang dan gizi buruk di kota Padang, karena penanganan masalah gizi kurang dan gizi buruk belum maksimal. Kasus kurang gizi dan gizi buruk paling banyak ditemukan berada di Kecamatan Padang Selatan, Kecamatan Nanggalo dan Koto Tangah. Puskesmas Seberang Padang, tercatat 15 kasus gizi buruk dan 25 kasus gizi kurang hingga saat ini. Posyandu Anggrek 2 adalah posyandu yang memiliki anggota terbanyak diantara posyandu lain yang berada di Kecamatan Padang Selatan, dimana Posyandu Anggrek 2 memiliki anggota 65 anak. Pada posyandu ini ditemukan 10 kasus gizi buruk sedangkan pada tahun 2019 ditemukan 12 anak mengalami gizi buruk yang perlu dirawat inap di puskesmas dengan berbagai komplikasi penyakit serius.

Menurut hasil penelitian Riset Kesehatan Dasar (Rikesdas) secara nasional pada 2013, di Indonesia terdapat 23.708.884 balita dan yang mengalami gizi buruk 19,6 persen atau 4.646.933 balita (Litbang Depkes RI tahun 2015). Rata-rata setiap provinsi lebih dari 13 persen masih terdapat balita dengan status gizi buruk. Ini menunjukkan bahwa dua dari 10 balita di Indonesia masih mengalami gizi buruk.

Penilaian status gizi balita pada Riskesdas 2013 dilakukan melalui pengukuran berat dan tinggi/panjang badan. Kemudian nilai status gizi dihitung berdasarkan nilai Z-skor tinggi badan menurut umur $(\mathrm{TB} / \mathrm{U})$ untuk mendapatkan indikator balita pendek dan sangat pendek, berat badan menurut umur $(\mathrm{BB} / \mathrm{U})$ untuk mendapatkan indikator gizi buruk dan gizi kurang.

Penanganan masalah gizi yang belum maksimal, sampai saat ini, masih ditemukan banyak balita yang mengalami gizi kurang dan gizi buruk berdasarkan pengamatan yang dilakukan pada beberapa kelompok posyandu termasuk Posyandu Anggrek 2 yang terdapat di Kecamatan Padang Selatan. Dari data yang tercatat dari Puskesmas Sebarang Padang ditemukan beberapa faktor penyebab gizi buruk akibat bawaan sejak lahir karena selama kehamilan kurang memperhatikan gizi akibatnya, bayi menderita penyakit sejak dalam kandungan, kurang asupan ASI, kurangnya kesadaran orangtua mengontrol imunisasi dan pola asuh yang salah seperti memaksakan memberi makanan pada bayi yang umurnya di bawah 6 bulan, kurangnya kesadaran ibu untuk membawa balitanya ke posyandu, orangtua cenderung lalai pada masa usia rawan anak, sedangkan pada usia tersebut anak sangat butuh nutrisi, gizi dan perhatian yang baik dari orang tua.

Perbaikan gizi untuk balita dengan pemberian mikroalga Spirulina dalam menu keluarga terutama balita dapat meningkatkan gizi dalam waktu cepat dibandingkan menu makanan lain karena kandungan nutrisi yang tinggi dan lengkap. Mikroalga Spirulina platensis sebagai suplemen gizi untuk balita yang mengalami gizi kurang dan gizi buruk, karena mikroalga spirullina memiliki kandungan nutrisi yang lengkap yaitu protein yang tinggi (Bradbury, 2011), asam lemak yang baik untuk perkembangan otak yang maksimal pada balita karena memiliki asam lemak omega-3 (ALA, EPA dan DHA) (Nugraha et al, 2015; Susanti at al 2013), asam lemak ini juga penting untuk ibu hamil dan menyusui, untuk perkembangan otak dan mata bayi (Afterburn, et al., 2008; Bourre, 2007). Kandungan Lipid pada mikroalga sangat baik untuk mengendalikan obesitas pada balita dengan status gizi kelebihan berat badan (Armaini, et al, 2020) 
Website. http://hilirisasi.lppm.unand.ac.id e-ISSN: 2621-7198

Mikroalga Scenedesmus dimorphus yang di kultur dalam media BBM dengan sumber nitrogen urea mampu menghasilkan karotenoid yang tinggi, seperti beta-karoten sebagai provitamin A dan karotenoid (Armaini, et al. 2016) juga dikenal memiliki nilai terapeutik, termasuk anti-inflmmatory dan anti-kanker (Iyer et al., 2008). Mikroalga Scenedesmus dimorphus bermanfaat sebagai anti-anemia karena memiliki anti oksidan tinggi, asam folat dan zat besi (Armaini et al, 2018). Miroalga mengandung antioksidan yang cukup tinggi dan berbagai vitamin yang penting untuk kesehatan (Becker et al., 2004; Chu et al., 2010). Kegiatan Program Kemitraan Masyarakat yang dilaksanakan di Posyandu Anggrek 2 bertujuan meningkatkan gizi dan imunitas balita dengan pemberian suplement Spirulina platensis pada kondisi pandemi saat ini.

\section{METODOLOGI}

Pelaksanaan kegiatan dilakukan di Posyandu Anggrek 2 di Kelurahan Seberang Padang Kecamatan Padang Selatan Kota Padang, Pada kegiatan Program Kemitraan Masyarakat dengan kondisi pandemi COVID-19 tidak dapat mengumpulkan orang dalam jumlah yang banyak maka kami memutuskan hanya mengambil 10 balita dengan gizi kurang dan gizi buruk dengan berbagai pertimbangan kondisi dan situasi saat ini. Kegiatan PKM dilaksanakan dengan tahapan sebagai berikut ;

\section{Obserbvasi}

Pengamatan dilapangan dilakukan dengan cara mencatat data secara sistematis terhadap fenomena dan gejala sosial yang berlangsung di lapangan dalam upaya menggali data kualitatif yang diukur secara tidak langsung. Observasi dilakukan untuk memperoleh data kualitatif seperti, tingkat pendidikan orangtua balita, tingkat ekonomi dan jumlah anak dalam keluarga. Observasi dilakukan terhadap ibu dari balita gizi kurang dan gizi buruk yang tergabung dalam posyandu Anggrek 2, untuk mengetahui riwayat kelahiran anak apakah anak lahir dengan berat lahir rendah (BLR), lama waktu pemberian ASI, usia bayi saat diberi makanan tambahan, pola asuh balita, dan menu harian balita.

\section{Sosialisasi Makanan Bergizi}

Ibu rumah tangga yang tergabung dalam kelompok Posyandu Anggrek 2 akan diberikan pengetahuan tentang makanan bergizi dan pentingnya makanan bergizi untuk kesehatan keluarga dan tumbuh kembangnya balita. Mensosialisasikan makan dengan kandungan nutrisi tinggi khususnya mikroalga Spirullina dan memberikan pengetahuan tentang kandungan gizi Spirullina yang sangat bermanfaat untuk meningkatkan gizi keluarga terutama balita.

Meningkatkan pengetahuan ibu rumah tangga bagaimana cara pengolahan bahan makanan agar tidak kehilangan nilai nutrisinya dan cara pengolahan mikroalga Spirullina dalam menu keluarga dan membiasakan keluarga untuk mengkonsumsi mikroalga Spirullina. Peningkatan ilmu pengetahuan tentang gizi untuk ibu rumah tangga dilakukan dengan memberikan materi tentang pentingnya makanan bergizi untuk kesehatan, perkembangan pertumbuhan anak, meningkatkan kecerdasan dan ketahanan tubuh terhadap penyakit. 


\section{Teknologi Budidaya Spirullina platensis}

Tempat untuk membudidayakan mikroalga digunakan wadah Galon Transparant (bening) dengan kapasitas volume 20 liter. Wadah dilengkapi dengan aerator dan lampu dengan intensitas cahaya $50 \mu \mathrm{mol} \mathrm{m}^{-2} \mathrm{~s}^{-1}$ dengan perbandingan 14:10 jam (terang:gelap) sebagai pengganti cahaya matahari. Ke dalam galon dimasukkan 10 liter air bersih dan tambahkan 1 saset formula pemupukan mikroalga aduk rata diamkan selama 2 jam. Komposisi formula pemupukan terdiri dari $160 \mathrm{~g} \mathrm{NaHCO}, 10 \mathrm{~g} \mathrm{Na} \mathrm{Cl}$, $20 \mathrm{~g} \mathrm{KNO}_{3}$ dan $1 \mathrm{~g}$ Ammonium fosfat. Kedalam media yang sudah disiapkan masukan kultur mikroalga, amati pertumbuhan mikroalga per-minggu. Pertumbuhan mikroalga diukur optical density (OD) menggunakan spektrofotometer pada $550 \mathrm{~mm}$ (Armaini at al, 2018)

\section{Pemberian Menu makanan mengadung biomassa Spirullina}

Pemberian mikroalga Spirullina dengan frekwensi 1 kapsul per-hari selama 6 minggu pada menu makanan balita gizi kurang dan gizi buruk, dan 2 hari sekali 1 kapsul untuk balita gizi baik. Pengukuran berat dan tinggi badan balita berdasarkan umur sebagi indikator keberhasilan dalam perbaikan gizi, pertambahan berat dan tinggi badan balita diukur per-2-minggu Menurut Keputusan Mentri Kesehatan RI No no.1995/MENKES/SK/XII/2010 klasifikasi status gizi balita berdasarkan nilai indeks Antropometri (berat badan/umur dan tinggi badan/umur) dibandingkan dengan nilai rujukan nilai WHO-NCHS. Indikator ini akan digunakan untuk mengamati keberhasilan mikroalga sebagai suplemen gizi yang dapat meningkatkan status gizi balita dari status gizi kurang dan gizi buruk meningkat menjadi status gizi baik.

\section{Pelaksanaan Kegiatan Lapangan}

Pelaksanaan PKM di lokasi Posyandu Anggrek 2 dilakukan dengan protokol COVID-19. Jumlah peserta kegiatan dibatasi jumlah total orang berkumpul menurut protokol COVID-19 harus kurang dari 30 orang untuk dapat dilakukan pembatasan jarak yaitu 1 meter. Jumlah peserta dibatasi menjadi 10 orang balita dengan 10 orang tuanya, 4 orang kader Posyandu 1 Orang penanggung jawab dari puskesmas dan 5 orang tim pelaksana PKM. Kegiatan dilakukan dengan melaksanakan protokol Covid-19 yaitu memberikan fasilitas sesuai protokol Covid-19 yang terdiri dari: 1) pengukuran suhu badan setiap peserta menggunakan Thermometer Infrared (Thermogun), 2) menyediakan face shield untuk orang dewasa dan balita, 3) menyediakan masker untuk peserta dewasa dan balita 4) menyediakan tempat pencuci tangan dan sabun, 5) menyediakan hand sanitizer.

\section{HASIL DAN PEMBAHASAN}

\section{Hasil Kegiatan Pelaksanan PKM di Posyandu Anggrek 2 \\ 1. Oserbvasi}

Berdasarkan hasil observasi dilapangan yang dilakukan dari rumah ke rumah (door to door) diperoleh kondisi keluarga balita yaitu tingkat pendidikan orang tua balita, tingkat ekonomi dan jumlah anak dalam keluarga, hasil observasi diperoleh ditampilkan pada Tabel 1. 
Website. http://hilirisasi.lppm.unand.ac.id e-ISSN: 2621-7198

Tabel.1 Hasil Observasi Mengenai Kondisi Keluarga Responden

\begin{tabular}{lccc}
\hline \multicolumn{1}{c}{ Anggota Posyandu } & $\begin{array}{c}\text { Tingkat pendidikan Orang } \\
\text { tua }\end{array}$ & Jumlah Anak & Penghasilan Orang Tua \\
\hline Anak Perempuan & & 3 & \\
Balita 1 & SMA & 4 & $>3$ juta \\
Balita 2 & SMP & 4 & $2-3$ juta \\
Balita 3 & SMP & 2 & $<1,5$ juta \\
Balita 4 & SMA & & $>3$ juta \\
& & 3 & \\
Anak laki-laki & SD & 4 & $2-3$ juta \\
Balita 5 & SD & 2 & $2-3$ juta \\
Balita 6 & SMA & 3 & $>3$ juta \\
Balita 7 & SMA & 2 & $2-3$ juta \\
Balita 8 & SMP & 4 & $<1,5$ juta \\
Balita 9 & SD & & \\
Balita 10 & & 3 juta \\
\hline
\end{tabular}

Berdasarkan Tabel 1. hasil observasi diperoleh bahwa kondisi keluarga sangat mempengaruhi status gizi balita. Keluarga yang memiliki penghasil $<1,5$ juta rupiah per-bulan dan 2-3 juta per-bulan dan tidak memiliki penghasilan tetap dengan tingkat pendidikan yang rendah (SD dan SMP) memiliki pengetahuan tentang makanan bergizi sangat kurang dan jumlah anak yang lebih dari 2 orang menjadi faktor penyebab balita mengalami gizi buruk dan gizi kurang. Keluarga dengan tingkat penghasilan lebih tinggi yaitu $>3$ juta rupiah dengan penghasilan tetap dan tingkat pendidikan yang cukup (SMA) serta memiliki pengetahuan yang cukup baik tentang makanan bergizi dan sehat, memiliki balita dengan status gizi baik.

Status gizi balita sangat dipengaruhi oleh status ekonomi keluarga, tingkat pendidikan orang tua dan jumlah anak dalam keluarga. Berdasarkan hasil penelitian Riset Kesehatan Dasar (Rikesdas) secara nasional pada 2013 dan hasil survei dari Litbang Depkes RI tahun 2015 bahwa status ekonomi keluarga sangat mempengaruhi status gizi balita serta pengetahuan orang tua tentang makanan sehat dan bergizi juga mempengaruhi status gizi balita..

\section{Produksi Biomasa Spirulina platensis}

Perbanyakan kultur Spirulina platensis untuk produksi 10 galon untuk memproduksi biomasa pada tahap pertama (Gambar 1a) kultur ditumbuhkan selama 8 hari kemudian dipanen dengan menyaring kultur mikroalga Spirulina dan dikeringkan untuk mendapatkan biomasa kering, kemudian dimasukkan ke dalam kapsul untuk diberikan pada orang tua balita. Biomasa kering diperoleh dengan berat antara 98,5 gram dari 10 galon kultur (Gambar 1b). 


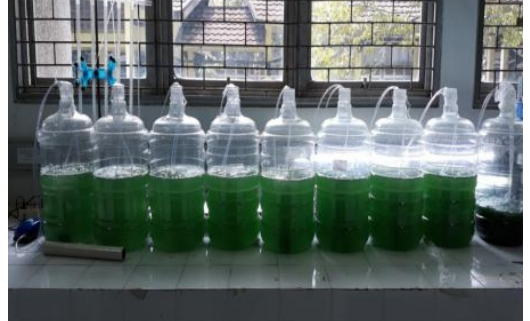

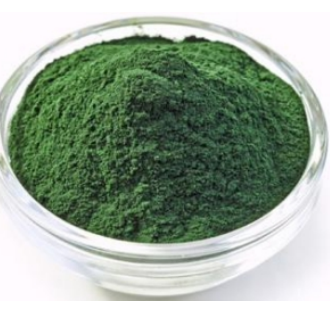

b

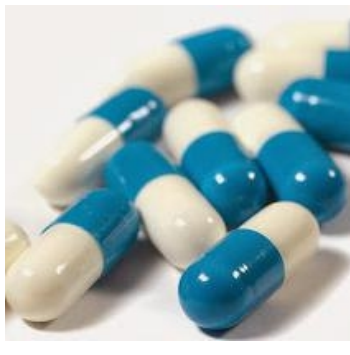

C

Gambar 1. a) Produksi mikroalga Spirulina platensis untuk menghasilkan biomasa dalam jumlah besar, b) biomasa kering hasil produksi dan c) kapsul Spirulina platensisi

\section{Status Gizi Awal Balita}

Hasil pengukuran berat badan dan tinggi badan pada kondisi awal sebelum pemberian Spirullina platensis seperti terlihat pada tabel 2 dan tabel 3. Status gizi awal dari 10 balita terdapat 4 balita gizi buruk, 3 balita gizi kurang dan 3 balita gizi baik (tabel 2). Berdasarkan hasil observasi (tabel 1) anak yang mengalami gizi buruk dan gizi kurang berasal dari keluarga yang kurang mampu (penghasilan keluarga yang tidak tetap), pendidikan orang tua yang rendah (SD dan SMP) dengan pengetahuan tentang gizi anak yang rendah dan jumlah anak dalam keluarga lebih dari 2 orang.

Berdasarkan indeks Antropometri (berat badan/umur dan tinggi badan/umur ) untuk menentukan status gizi balita merujuk pada Surat Keputusan Menteri Kesehatan Republik Indonesia (SK MEMKES No: 1995/MENKES/SK/XI/2010). Balita gizi buruk bila indek Z-Score nya <-3SD, gizi kurang indek Z-Score -3SD s/d -2SD dan gizi baik Z-Score -2SD s/d 2SD. Pada tabel 2 terlihat pengukuran berat badan menurut umur terdapat 4 orang balita dengan status gizi buruk, 3 balita status dengan gizi kurang dan 3 balita status gizi baik.

Tabel 2. Status Gizi awal balita sebelum diberikan Spirullina platensis berdasarkan pengukuran berat badan menurut umur (BB/U).

\begin{tabular}{|c|c|c|c|c|c|}
\hline No & Balita & $\begin{array}{c}\text { Umur } \\
\text { (Bulan) }\end{array}$ & $\begin{array}{c}\text { BB } \\
(\mathrm{Kg})\end{array}$ & Z-Score & $\begin{array}{c}\text { Status Gizi } \\
(\mathrm{BB} / \mathrm{U})\end{array}$ \\
\hline & Anak Perempuan & & & & \\
\hline 1 & Balita 1 & 17 & 9,4 & $-2 \mathrm{SD}$ s/d 2SD & baik \\
\hline 2 & Balita 2 & 17 & 7,8 & $-3 \mathrm{SD} s / \mathrm{d}-2 \mathrm{SD}$ & kurang \\
\hline 3 & Balita 3 & 25 & 8,0 & $<-3 \mathrm{SD}$ & buruk \\
\hline 4 & Balita 4 & 25 & 10,2 & $-2 \mathrm{SD} \mathrm{s} / \mathrm{d} 2 \mathrm{SD}$ & baik \\
\hline & Anak laki-laki & & & & \\
\hline 5 & Balita 5 & 17 & 8,1 & $-3 \mathrm{SD} s / \mathrm{d}-2 \mathrm{SD}$ & kurang \\
\hline 6 & Balita 6 & 29 & 8,1 & $<-3 \mathrm{SD}$ & buruk \\
\hline 7 & Balita 7 & 41 & 12,0 & $-3 \mathrm{SD} s / \mathrm{d}-2 \mathrm{SD}$ & kurang \\
\hline 8 & Balita 8 & 41 & 9,8 & $<-3 \mathrm{SD}$ & buruk \\
\hline 9 & Balita 9 & 48 & 12,8 & $-2 \mathrm{SD} s / \mathrm{d} 2 \mathrm{SD}$ & baik \\
\hline 10 & Balita 10 & 55 & 8,2 & $<-3 \mathrm{SD}$ & Buruk \\
\hline
\end{tabular}

$\mathrm{BB}=$ berat badan, $\mathrm{BB} / \mathrm{U}=$ berat badan menurut umur 
Website. http://hilirisasi.lppm.unand.ac.id e-ISSN: 2621-7198

Tabel 3. Status Gizi awal balita sebelum diberikan Spirullina platensis berdasarkan pengukuran tinggi badan menurut umur (TB/U).

\begin{tabular}{|c|c|c|c|c|c|}
\hline No & Balita & $\begin{array}{c}\text { Umur } \\
\text { (Bulan) }\end{array}$ & $\begin{array}{c}\text { TB } \\
(\mathrm{cm})\end{array}$ & Z-Score & $\begin{array}{l}\text { Status Gizi } \\
(\mathrm{TB} / \mathrm{U})\end{array}$ \\
\hline & Anak Perempua & & & & \\
\hline 1 & Balita 1 & 17 & 76 & $-2 \mathrm{SD} \mathrm{s} / \mathrm{d} 2 \mathrm{SD}$ & normal \\
\hline 2 & Balita 2 & 17 & 72 & $-3 \mathrm{SD} s / \mathrm{d}-2 \mathrm{SD}$ & pendek \\
\hline 3 & Balita 3 & 25 & 78 & $-3 \mathrm{SD} \mathrm{s} / \mathrm{d}-2 \mathrm{SD}$ & pendek \\
\hline \multirow[t]{2}{*}{4} & Balita 4 & 25 & 82 & $-2 \mathrm{SD}$ s/d $2 \mathrm{SD}$ & normal \\
\hline & Anak laki-laki & & & & \\
\hline 5 & Balita 5 & 17 & 80 & $-3 \mathrm{SD} s / \mathrm{d}-2 \mathrm{SD}$ & normal \\
\hline 6 & Balita 6 & 29 & 81 & $<-3 \mathrm{SD}$ & sangat pendek \\
\hline 7 & Balita 7 & 41 & 90 & $-3 \mathrm{SD} s / \mathrm{d}-2 \mathrm{SD}$ & pendek \\
\hline 8 & Balita 8 & 41 & 82 & $<-3 \mathrm{SD}$ & sangat pendek \\
\hline 9 & Balita 9 & 48 & 94 & $-2 \mathrm{SD} s / \mathrm{d} 2 \mathrm{SD}$ & pendek \\
\hline 10 & Balita 10 & 55 & 80 & $<-3 \mathrm{SD}$ & Sangat pendek \\
\hline
\end{tabular}

Keterangan:

$\mathrm{TB}=$ tinggi badan, $\mathrm{TB} / \mathrm{U}=$ tinggi badan menurut umur

Pada awal pengukuran tinggi badan balita menurut umur sebelum diberi perlakuan Spirullina platensis diperoleh status gizi balita seperti terlihat pada tabel 3 . Balita dengan status gizi buruk memiliki tinggi badan yang sangat pendek pada 3 balita dan 1 balita dengan tinggi badan pendek, dan balita dengan status gizi kurang memiliki tinggi badan yang pendek pada 3 balita, sedangkan balita dengan status gizi baik dengan tinggi badan yang normal pada 3 balita. Badan yang pendek atau sangat pendek (stunting) umumnya terjadi pada balita dengan status gizi kurang dan gizi buruk, hal disebabkan tumbuh kembang balita terhambat karena asupan gizi yang kurang selama masa pertumbuhan anak terutama pada balita usia emas di bawah 2 tahun, ini yang sering terjadi pada balita.

Gizi buruk merupakan suatu keadaan kekurangan konsumsi zat gizi yang disebabkan oleh rendahnya konsumsi energi protein dalam makanan sehari-hari, masalah kurang gizi dapat mencakup kekurangan energi, protein, zat besi, juga kekurangan vitamin A dan vitamin B komplek (Ramachandran at al, 2006)

Faktor penyebab gizi kurang dan gizi buruk terjadi karena kondisi ekonomi yang rendah, kurang memahami pentingnya asupan ASI pada masa pemberian ASI eklusif, kurangnya kesadaran orangtua mengontrol imunisasi dan pola asuh yang salah seperti memaksakan memberi makanan tambahan pada bayi yang umurnya di bawah 6 bulan, menu makan yang tidak seimbang pada balita karena orang tua kurang memiliki pengetahuan tentang makanan bergizi hal dapat disebabkan tingkat pendidikan orang tua yang rendah (Reynaldo et al 2012).

Balita dengan gizi kurang dan gizi buruk memiliki resiko tinggi terkena penyakit infeksi (bakteri dan virus), karena sistem kekebalan tubuh yang rendah sehingga rentan terhadap penyakit karena kekurangan nutrisi dalam tubuh (Uauy at el. 2008). Faktor sosial ekonomi dan demografis berhubungan dengan pola stunting (pendek) dan Wasting (kurus) pada anak di seluruh dunia (Frongillo et al, 1997)

\section{Peningkatan Gizi Balita dengan kapsul Spirullina platensis.}

Biomasa kering Spirullina platensis yang kaya protein, lemak baik (omega-3 dan omega-6 dan PUFA), karbohidrat, antioksidan dan anti imflamasi yang sangat 
Website. http://hilirisasi.lppm.unand.ac.id e-ISSN: 2621-7198

penting untuk meningkatkan gizi dan imunitas anak. Biomasa Spirullina platensis di kemas dalam kapsul berisi 0,5 g setiap kapsul. Pemberian Spirullina platensis pada balita meningkatkan gizi yang dievaluasi nilai indeks Antropometri (berat badan/umur, dan tinggi badan/umur ) untuk menentukan status gizi dirujuk berdasarkan Surat keputusan Menteri Kesehatan Republik Indonesia (No. 1995/MENKES/SK/XII/2010) dibandingkan dengan nilai rujukan nilai WHO-NCHS.

Tabel 4. Hasil Pengukuran Peningkatan Berat Badan Berdasarkan Umur Awal dan Setelah 6 minggu Pemberian Spirullina Platensis

\begin{tabular}{|c|c|c|c|c|c|c|}
\hline \multirow[t]{2}{*}{ No } & Nama Balita & \multicolumn{2}{|c|}{$\begin{array}{c}\text { Umur (Bulan) } \\
\text { Awal Akhir }\end{array}$} & \multicolumn{2}{|c|}{$\begin{array}{c}\text { Berat Badan (kg) } \\
\text { Awal akhir }\end{array}$} & \multirow[t]{2}{*}{$\begin{array}{c}\text { Status Gizi } \\
\text { Akhir }\end{array}$} \\
\hline & Anak Perempuan & & & & & \\
\hline 1 & Balita 1 & 17 & 19 & 9,4 & 11,0 & baik \\
\hline 2 & Balita 2 & 17 & 19 & 7,8 & 9,2 & baik \\
\hline 3 & Balita 3 & 25 & 27 & 8,0 & 10,0 & baik \\
\hline \multirow[t]{2}{*}{4} & Balita 4 & 25 & 27 & 10,2 & 11,2 & baik \\
\hline & Anak laki-laki & & & & & \\
\hline 5 & Balita 5 & 17 & 19 & 8,1 & 10,0 & baik \\
\hline 6 & Balita 6 & 29 & 31 & 8,1 & 10,2 & baik \\
\hline 7 & Balita 7 & 41 & 43 & 12 & 13,5 & baik \\
\hline 8 & Balita 8 & 41 & 43 & 9,8 & 12,1 & kurang \\
\hline 9 & Balita 9 & 48 & 50 & 12,8 & 14,0 & baik \\
\hline 10 & Balita 10 & 55 & 57 & 8,2 & 12,5 & kurang \\
\hline
\end{tabular}

Keterangan: Awal = Sebelum diberi Spirullina platensis

Akhir $=$ Setelah pemberian Spirullina platensis selama 6 minggu

Tahap selanjutnya pada 10 balita diberikan Spirullina platensis untuk ditingkatkan status gizinya. Pemberian Spirullina platensis pada balita gizi kurang dan gizi buruk diberikan dengan dosis 1 kapsul $(500 \mathrm{mg})$ per-hari dan untuk balita dengan gizi baik diberikan dua hari sekali 1 kapsul selama 6 minggu untuk meningkatkan gizi dan imunitas di masa pandemi Covid-19.

Berdasarkan hasil penimbangan berat badan balita dilakukan menggunakan timbangan badan digital, pengamatan dilakukan setiap minggu selama 6 minggu perlakuan dengan pemberian kapsul Spirullina platensis diperoleh hasil seperti tabel 4, pertambahan berat badan memperlihatkan hasil yang signifikan dan memberikan peningkatan status gizi balita dari gizi kurang pada 3 balita menjadi gizi baik dan peningkatan status gizi dari 2 balita dari gizi buruk menjadi kurang gizi.

Pada balita dengan status gizi buruk membutuhkan waktu perbaikan gizi lebih lama karena tidak dapat dilakukan peningkatan gizi secara drastis pada balita karena berdampak tidak baik bagi kesehatan anak.

Hasil pengukuran pertambahan tinggi badan berdasarkan umur setelah pemberian Spirullina platensis selama 6 minggu seperti yang ditampilkan pada tabel 5 . Terjadi pertambahan tinggi badan pada semua balita, terjadi peningkatan status gizi pada 3 balita dari pendek menjadi normal dan 1 balita dari sangat pendek menjadi pendek. 
Website. http://hilirisasi.lppm.unand.ac.id

e-ISSN: 2621-7198
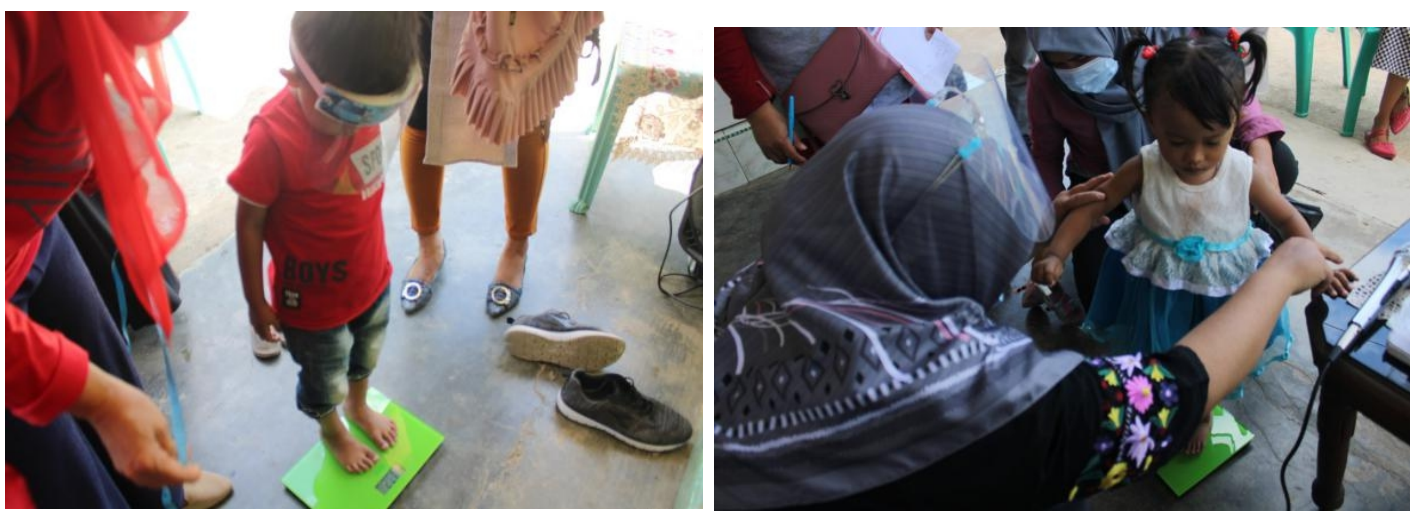

Gambar 2. Penimbangan Berat Badan Anak Laki-Laki Berusia 4 Tahun 7 Bulan dengan Berat Badan 8,2 Kg Dengan Kondisi Gizi Buruk Dan Anak Perempuan Umur 2 Tahun 1 Bulan Berat 8 Kg dengan Kondisi Kurang Gizi.

Tabel 5. Hasil Pengukuran Pertambahan Tinggi Badan Berdasarkan Umur (TB/U) Awal dan Setelah 6 Minggu Pemberian Spirullina platensis

\begin{tabular}{clccccc}
\hline No & Nama Balita & \multicolumn{2}{c}{$\begin{array}{c}\text { Umur (Bulan) } \\
\text { Awal Akhir }\end{array}$} & $\begin{array}{c}\text { Tinggi Badan (cm) } \\
\text { Awal akhir }\end{array}$ & $\begin{array}{c}\text { Status Gizi } \\
\text { Akhir }\end{array}$ \\
\hline \multirow{2}{*}{$\begin{array}{l}\text { Anak Perempuan } \\
\text { 1 }\end{array}$} & Balita 1 & 17 & 19 & 76 & 79 & normal \\
2 & Balita 2 & 17 & 19 & 72 & 75 & normal \\
3 & Balita 3 & 25 & 27 & 78 & 80 & pendek \\
4 & Balita 4 & 25 & 27 & 82 & 86 & normal \\
& & & & & & \\
& Anak laki-laki & & & & & normal \\
5 & Balita 5 & 17 & 19 & 80 & 84 & pendek \\
6 & Balita 6 & 29 & 31 & 81 & 84 & normal \\
7 & Balita 7 & 41 & 43 & 90 & 95 & Sangat pendek \\
8 & Balita 8 & 41 & 43 & 82 & 87 & normal \\
9 & Balita 9 & 48 & 50 & 94 & 98 & Sangat pendek \\
10 & Balita 10 & 55 & 57 & 80 & 86 & \\
\hline
\end{tabular}

Keterangan: Awal $=$ Sebelum diberi Spirullina platensis

Akhir $=$ Setelah pemberian Spirullina platensis selama 6 minggu

Pada 2 balita (balita 8 dan 10) walaupun terjadi pertambahan tinggi badan tapi status gizi tetap yaitu sangat pendek. Pemberian Spirullina platensis selama 6 minggu dapat meningkatkan status gizi pada 3 balita gizi kurang dan 4 balita gizi buruk menjadi 5 balita gizi normal dan 2 balita dari gizi buruk menjadi kurang gizi. Hal ini disebabkan Spirullina platensis suplemen yang memiliki nutrisi yang sangat baik karena kandungan protein tinggi, lipid yang baik untuk kesehatan (omega-3 dan omega-6 dan PUFA) karbohidrat yang sangat penting untuk meningkatkan gizi pada balita (Armaini et al, 2016; Nugraha et al, 2015).

Spirullina platensis memiliki kandungan antioksidan dan anti-imflamasi yang penting untuk meningkatan imunitas anak dan kaya vitamin Vit B-1, B-2, B-6, B-12, Beta-karoten (Pro-Vit A), E, K, Botin, Nasin (meningkatan metabolisme tubuh mencegah malnutrisi) dan asam Folat (untuk meningkatkan kecerdasan. Spirullina platensis kaya mineral seperti kalsium, besi, magnesium, selenium, mangan, kalium, 
dan seng (penting untuk pembentukan tulang dan memperbaiki sel darah merah berpotensi untuk menghambat pertumbuhan sel leukimia pada manusia).
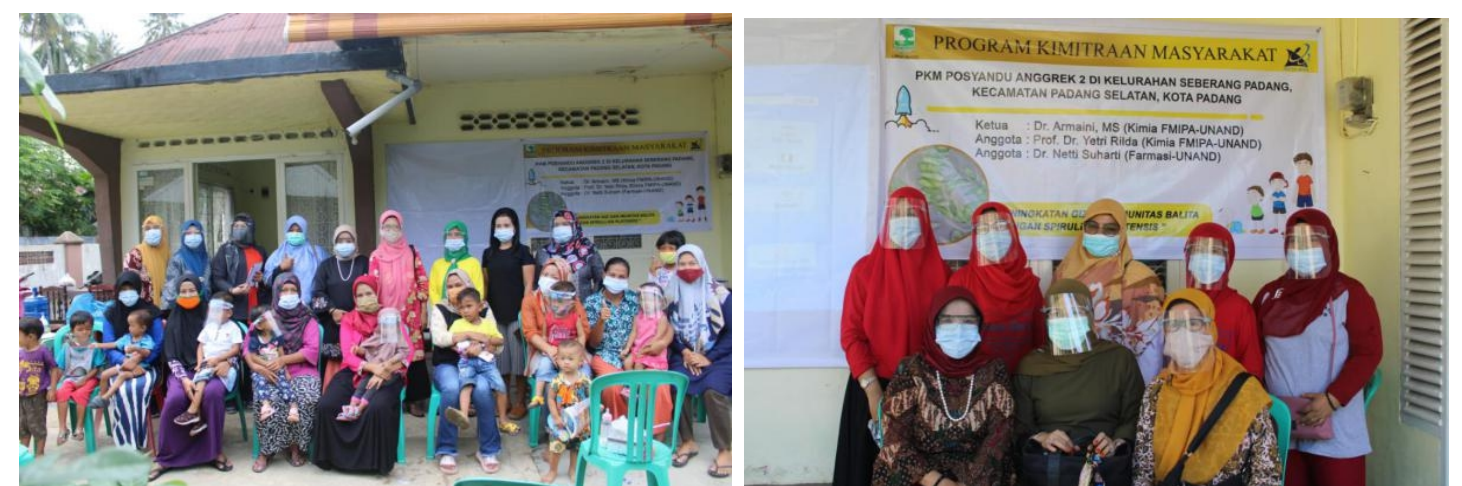

Gambar 3. Peserta kegiatan PKM terdiri dari balita dan orang tua nya serta tim pelaksana PKM dan Mitra kadar Posyandu Anggrek 2 beserta tim dari Puskesmas Sebarang Padang Kecamatan Padang Selatan

\section{KESIMPULAN DAN SARAN}

Pelaksanaan kegiatan di Posyandu Anggrek 2 diperoleh bahwa faktor utama penyebab balita mengalami gizi kurang dan gizi buruk adalah status ekonomi, tingkat pendidikan dan jumlah anak dalam keluarga. Kegiatan PKM yang dilaksanakan dengan pemberian Spirullina platensis makanan kaya gizi pada menu harian balita dapat meningkatkan gizi dan imunitas. Peningkatan gizi ditandai dengan pertambahan berat badan dan status gizi menurut indeks Antropometri. Spirullina platensis dengan kandungan antioksidan yang tinggi dapat meningkatkan imunitas balita pada masa pandemi saat ini.

\section{UCAPAN TERIMA KASIH}

Tim pelaksana Program Kemitraan Masyarakat mengucapkan terima kasih kepada Direktorat Riset dan Pengabdian Masyarakat, Deputi Bidang Penguatan Riset dan Teknologi/Badan Riset dan Inovasi Nasional yang telah memberikan dana, sesuai dengan kontrak Pelaksanaan Program Pengabdian Masyarakat Nomor: 047/SP2H/PPM/DRPM/2020 tanggal 16 Maret 2020, Tahun Anggaran 2020.

\section{DAFTAR PUSTAKA}

Afterburn LM, Oken HA, Hall HB, Hamersley J, Kuratko CN, Hoffman JP. 2008. Algal-Oil capsules and cooked salmon: nutritionall equivalent sources of docosahexaenoic acid. J Am Diet Assoc. 108: 1204-1209. 
Armaini A, Dharma A, Salim M. 2020. The nutraceutical effect of Scenedesmus dimorphus for obesity and nonalcoholic fatty liver disease-linked metabolic syndrome. J Appl Pharm Sci; 10(05):070-076.

Armaini A, Salim M, Pribadi P. 2018. Induction Effect of Scenedesmus dimophus Against Hematology on Mice Suffering Anemia Diseases. Asian Journal Phamaceutical and Clinical Reseach. 11(7): 348-352 .

Armaini A, Salim M, Rinaldi R. 2016. Influence of urea concentration on biomass, pigment, lipid and protein content of Scenedesmus dimorphus microalgae Der Pharma. Chemica J. 8: 13.

Becker W. Microalgae in human and animal nutrition. 2004. In: Richmond A, ed. Handbook of microalgal culture: Biotechnology and Applied Phycology. Oxford: Blackwell Science, 312-351.

Bradbury, J. 2011. Docosahexaenoic Acid (DHA): An Ancient Nutrient for the Modern Human Brain. Review Article. Nutrients, 3, 529-554.

Bourre, JM 2007. Dietary omega-3 fatty acids for women. Biomed Pharmacother, 61(2-3):105-112.

Chu WL, Lim YW, Radhakrishnan AK, Lim PE. 2010. Protective effect of aqueous extract from Spirulina platensis against cell death induced by free radicals. BMC Complement Altern Med; 10: 53.

Chu WL. 2011. Potential applications of antioxidant compounds from algae. Curr Top Nutraceut Res ; 9: 83-98

Frongillo EA, Mercedes de Onis Jr. and Kathleen M. P. H. Socioeconomic and Demographic Factors Are Associated with WorldwidePatterns of Stunting and Wasting of Children. American Society for Nutritional Sciences. 1997

Indonesia, Badan Penelitian dan Pengembangan Kesehatan, Kementerian Kesehatan. Laporan nasional riset kesehatan dasar 2018. Jakarta: Lembaga Penerbit Badan Penelitian dan Pengembangan Kesehatan, 2019.

Indonesia, Badan Penelitian dan Pengembangan Kesehatan. Laporan Riset Kesehatan Dasar 2013. Jakarta: Lembaga Penerbit Badan Penelitian dan Pengembangan Kesehatan; 2013.

Iyer UM, Dhruv SA, Mani IU. Spirulina and its therapeutic implications as a food product. In: Gershwin ME, Belay A, eds. Spirulina in human nutrition and health. Boca Raton: CRC Press, 2008: 51-70. 
Nugraha AD, Dharma A, Mardiah E, and Salim M. 2015. Effect of Urea Addition on Spirulina platensis Growth for Production of Lipid and Omega-3 Fatty Acids. Res. J. of Pharm, Biol. and Chem. Sci. 6(6) : 1005-10.

Rinaldi R, Armaini A, and Salim M. 2015. A Selection of Nitrogen Source for Biomass and Lipid Production of Scenedesmus dimorphus Microalgae. Res. J. of Pharm, Biol. and Chem. Sci. 6(3) : $143-147$.

Reynaldo Martorell and Melissa F. Young. Patterns of Stunting and Wasting:Potential Explanatory Factors. 2012 Adv. Nutr. 3: 227-233.

Ramachandran P, Gopalan HS. Assessment of nutritional status in In-dian preschool children using WHO 2006 Growth Standards. Indian J Med Res. 2011;134:47-53.

Suarez-Jimenez, G. M., Burgos-Hernandez, A. \& Ezquerra-Brauer, J. M. 2012. Bioactive Peptides And Depsipeptides With Anticancer Potential: Sources From Marine Animals. Mar Drugs, 10, 963-86.

Susanty, D., Oh-Hashi, K., Yamaguchi, Y., Tanakac, K., Yoshidab, S., Dharma, A., Munaf, E. \& Koketsu, M. 2013. Isolation, Identification And Fatty Acid Analysis Of Microalgae From West Sumatera, Indonesia J. Algal Biomass Utln. , 4, 7-13.

Uauy R, Kain J, Mericq V, Rojas J, Corvalán C. Nutrition, child growth,and chronic disease prevention. Ann Med. 2008; 40: 11-20. 